\title{
The Journal of Social Sciences Research
}

ISSN(e): 2411-9458, ISSN(p): 2413-6670

Vol. 6, Issue. 10, pp: 929-942, 2020

URL: https://arpgweb.com/journal/journal/7

DOI: https://doi.org/10.32861/jssr.610.929.942

\section{COVID-19 Lockdown in New York: A News Comparison Between the New York Times and Vice News}

\author{
Roslina Abdul Latif (Corresponding Author) \\ Taylor's University Lakeside Campus, Malaysia \\ Email: Roslina.AbdulLatif@taylors.edu.my
}

\author{
Andre Paul Marot \\ Taylor's University Lakeside Campus, Malaysia
}

\author{
Article History \\ Received: September 23, 2020 \\ Revised: October 24, 2020 \\ Accepted: October 28, 2020 \\ Published: October 31, 2020 \\ Copyright @ 2020 ARPG \& \\ Author \\ This work is licensed under the \\ Creative Commons Attribution \\ International \\ (c) (1) CC BY: Creative \\ Commons Attribution License \\ 4.0
}

\begin{abstract}
The Corona virus or also known as COVID-19 has raged the world with a devastating number of lives that were lost. During the lockdown and in the times of chaos, many have relied on the media for information to keep abreast with the updates of this angry virus. The objective of this study was to find out the differences of news coverage concerning the Covid-19 pandemic between mainstream and alternative media in New York City, where it hit the worst. The New York Times and Vice News were chosen to represent the mainstream and alternative news stations, respectively. The methodology used was a qualitative content analysis to organize, extract and understand the large data sets and derive conclusions. Conclusively, this analysis is based on four criteria's: headlines, sources, language, and visual images. A summary of the headline regarding the alternative resultantly informs us that Vice incorporates a majority of vague, misleading titles while contrastingly, the New York Times incorporates accurate and informative titles. Dissimilarities also occur with sources where a majority of citations are composed of sole informants for Vice News and multiple sources for the New York Times; authoritative and non-authoritative.
\end{abstract}

Keywords: COVID -19; Pandemic, Lockdown, The New York Times; Vice News.

\section{Introduction}

Media plays a role by giving information to the public. Mainstream media is everywhere, and publishes news through television, newspapers and the internet in the form of online publications (LaMarco, 2018). In the United States, mainstream media can be linked to few corporations that control most television networks, and newspapers. Generally, the audiences of mainstream media are more diverse, but they can be divided according to their different political views, and they tend to have larger audiences compared to alternative media.

Alternative media is referred to as "underground" press publications, which include newspapers, newsletters and other types of serial publications (LaMarco, 2018). This media is known for its publishing on an acknowledged political viewpoint in a liberal and conservative manner. However, it is said that they always have a specific agenda, to create more divisions between the society. Furthermore, they often report news to gain interest from a marginalized community without endorsing any defined ideology.

The objective of this study is to find the differences of news coverage concerning the Covid-19 pandemic in New York City between mainstream and alternative media. The New York Times and Vice News were chosen to represent the mainstream and alternative news stations. Both media have different values of coverage in this current issue. Usually, the media would tell the readers what they want to hear, rather than providing them with what they need to know.

\subsection{History of the Newspapers}

In 1994, Vice was established by Surrosh Alvi, Gavin McInnes and Smith with the aim to create an amusing, hip, and off-color magazine in Montreal which provided an outlet for the youth who considered mainstream culture conventional (Wiedeman, 2018). The media originated from New York and has an international network of digital systems, a TV production studio, a website, a music label, an in-house creative services company and a motion picture division, as their assets (Travis, n.d). Additionally, their business values were to put a great deal of effort into striking content which the media is known for utilizing through provocative photo stories (Sdun, 2015).

In April 1861, the creators of the New York Times, Henry Jarvis Raymond and George Jones declared in the first issue "We publish the first issue of the New-York Daily Times today, and we intend to publish it every morning (except Sundays) for an indefinite number of years to come." (First Versions, 2015). Their goal was simple: looking for the truth and helping their readers to understand the world (NYTCO, 2018). 


\subsection{Background of the first COVID -19 Case in New York}

New York's Governor Andrew Cuomo announced the first coronavirus case was in New York State on March 1, 2020. A woman contracted the virus while traveling in Iran and isolated herself (Goldstein and McKinley, 2020). The woman, 39, was a healthcare worker and started having respiratory symptoms when she returned home. The patient went to a hospital in New York City to get evaluated (Goldstein and McKinley, 2020) and the test revealed that the patient had SARS-CoV-2, but she had already taken several precautionary measures on returning home.

New York quickly became the epicenter of the pandemic in the United States with a record of 12,274 cases reported on April 4. Less than a week later it had more confirmed cases compared to other countries besides its own. The latest figures as of September 12, the state had reported 9.2 million tests, with 443,640 positive cases and 25,384 deaths (NYSDOH COVID-19 Tracker, 2020). In response, Governor Cuomo closed all non-essential services, and with the help of the Federal Emergency Management Center, transformed Manhattan's Javits Center into an emergency medical station with 2,910 beds (Myers Meghann, 2020).

At the beginning of the outbreak, New York State had 4,000 ventilators. Cuomo estimated that at least 30,000 would be needed over the next few weeks. Already nurses at the hospitals in Queens and Brooklyn were likening hospital wards to 'war zones' as the death toll in the city surpassed the 1,000 mark. In response, on March 30, the hospital shipped USNS Comfort (T-AH-20), a Mercy-class hospital ship of the United States Navy, with its 1000bed capacity to New York but it was not outfitted for coronavirus patients. They were contemplating whether it could be isolated for Covid-19 (Honigsbaum, 2020).

The scale of threat shattered public buildings and Broadway theatres and prompted Cuomo to issue a stay-athome order to protect the elderly and most vulnerable member of the community. The measure was called 'Mathilda's Law', named after his 88-year old mother. "This is an invisible beast, it is an insidious beast," he said in a clear-eyed address from the Javits Center (Harding, 2020). President Trump did not accept Cuomo's projections that as many as $140,000 \mathrm{New}$ Yorkers could be infected and that up to 40,000 might need ventilators. "I have a feeling that a lot of the numbers are just bigger than they're going to be," he told Fox News. It was also a cruel beast that because of the risk of infection, Covid-19 condemns patients to die alone, isolated from their families (Dowd, 2020).

No sooner were those words were out of his mouth, however, a Manhattan hospital announced the death of its first health worker, Kious Kelly, a 48-year-old assistant nursing manager at Mount Sinai West. Kelly had tested positive for Covid-19 on March 17, seven days after helping another nurse, who had been working with an infected patient remove a flimsy plastic gown she had been given by the hospital managers in lieu of personal protective equipment (PPE). Subsequently more pictures were posted on social media by other nurses at the same hospital showed them dressed in black trash bags with the caption 'NO more gowns in the whole hospital' (Honigsbaum, 2020). This was three months since Li Wenliang's chatroom post warning the whole world of the outbreak in Wuhan, China.

\subsection{Past Research on Pandemics}

The literature review for this research reveals the past influenza/H1N1 pandemic and Covid-19 situations and experiments done in various countries. Between all the journals, three of them used quantitative analysis. The quantitative methods examined preliminary studies investigating suspected risk or protection factors regarding the outcome. However, another journal used a quantitative analysis but did not specify the method. In the journal written by Mingwang Shen and his co-authors, based their data on the number of cases and deaths of Covid-19 from 15th January 2020 to 8th April 2020 (Shen et al., 2020).

The article written by Zoe B. Cheung and David A. Forsh, used the retrospective study to determine patients who were around 60 years old who had positive COVID-19 diagnostic testing and underwent primary hip fracture surgery at an institution during the outbreak from March 1, 2020 to May 22, 2020 (Cheung and Forsh, 2020). The data of the patient's demographic were collected, including age, gender, and medical comorbidities. Their clinical signs, laboratory testing and findings were also recorded. Similarly, Leonidas Palaiodimos, and his co-authors' used the study to examine how obesity affected the patients with Covid-19 and reviewed their electronic medical records independently in a pre-defined data extraction sheet Palaiodimos et al. (2020) The patients were also classified in three groups based on their body mass index (BMI).

Next, two other articles used both qualitative and quantitative research. The journal about the H1N1 pandemic by Allen Yu-Hung Lai, used interview statements and documents such as media reports and official documents within the 2009 cases in Singapore and Taiwan to retrieve data. Additionally, in this research, face-to-face interviews were also conducted (Lai, 2018). The interviewees' statements were then used as evidence to support or contest the argument.

Likewise, Micaela Fredi, Ilaria Cavazzana, Liala Moschetti, Laura Andreoli and Franco Franceschini's performed an observational case-control study at a public healthcare and research institution in the province of Brescia, one of the largest hospitals in Lombardy, Italy. The patients agreed to participate in the study with local regulations and signed consent forms upon admission to the hospital. Data was collected from February 24 until May 1,2020 through a survey that was administered by telephone and in the form of a pre-established interview (Fredi $e t$ al., 2020).

The last article written by Simin Ma, Xiaoquan Lai, Zhe Chen, Shenghao Tu and Kai Qin, used a qualitative analysis as they retrieved information from the patient's electronic medical records from 28 January 2020 to 29 February 2020 (Ma et al., 2020). 


\subsection{Sample Sizes}

The sample sizes in six journals were small. In the research written by Zoe B. Cheung, the sample size was 10 Covid-19 hip fracture patients who underwent surgery in New York City (Cheung and Forsh, 2020) and the largest sample size being only 1525 patients that enrolled in an outpatient clinic, which belonged to Micaela Fredi and the four co-authors' (Fredi et al., 2020). The sample size gathered by Allen Yu-Hung Lai was 20 informants from 12 organizations in Taiwan's communicable disease network and another 10 from eight different organizations in Singapore, which totals to 30 respondents (Lai, 2018). Followed by Simin Ma and the four co-authors', with a sample size of 95 adult patients at Tongji Hospital in Wuhan, China (Ma et al., 2020). Next, the research conducted by Leonidas Palaiodimos and seven other authors included 200 patients that were admitted to a tertiary medical center in The Bronx, New York (Palaiodimos et al., 2020). However, in Mingwang Shen and his seven co-authors' research, the sample size was not stated in the research but was done at the Hubei province in China (Shen et al., 2020).

\subsection{Findings}

The findings of each journal did not have many similarities. However, their findings were specific based on varied topics. In Allen Yu-Hung Lai's research it showed that the H1N1 event showed a major factor that affected organizational agility against the outbreak and related to the high level of uncertainty surrounding the disease. It argues that each determinant of agility contributed to an extent depending on the nature of the disease and played out differently for diseases with an unknown nature, such as Severe Acute Respitory Syndrome (SARS) (Lai, 2018).

The findings in the journal written by Simin Ma and the four co-authors showed that among the 95 Covid-19 patients, 44 were infected with influenza virus A, two with influenza virus B, one with adenovirus, and one with parainfluenza; 47 were uninfected. It added that patients with Covid-19 who had influenza, a co-infection, did not demonstrate different symptoms, as to someone with only Covid-19 (Ma et al., 2020).

Micaela Fredi and the four co-authors stated that, 117 patients were presented with symptoms that was compatible with COVID-19, 65 patients had a swab-confirmation of SARS-CoV-2 infection and 52 presented with symptoms indicative of COVID-19 but were not swab tested. This indicated that patients with rheumatic and musculoskeletal diseases do not appear to have a milder form of COVID-19 pneumonia than controls, therefore patients with other diseases most probably do not affect the chances of getting Covid-19 (Fredi et al., 2020).

Mingwang Shen and his seven co-authors', found that the metropolitan-wide quarantine strategy implemented in Hubei province might have reduced more than $70 \%$ of the Covid-19 cases. They also found that most of the virus' dissemination is by household transmission, despite quarantining (Shen et al., 2020). Furthermore, in Zoe B. Cheung and her co-authors, the article stated that 10 patients sustained hip fractures after a low velocity fall from standing height and seven of the patients tested Covid-19 positive. Eight out of the 10 patients had no symptoms of COVID19 , after undergoing surgery within two days of their admission in the hospital. However, the research stated that hip fracture patients represent a high-risk to getting Covid-19 as they were generally older with medical comorbidities (Cheung and Forsh, 2020).

Lastly, Leonidas Palaiodimos and seven other authors' article found that severe obesity is a factor for severe respiratory disease and death in hospitalized patients with COVID-19, hence people who are obese have a higher risk in getting the virus (Palaiodimos et al., 2020).

\section{Methodology}

The methodology used for the Covid-19, New York state study was a qualitative content analysis. The purpose of a qualitative content analysis was to organize, extract and understand large data sets and derive conclusions (Bengtsson, 2016).

\subsection{Search Parameters and Sample Sizes}

Search parameters were set in order to make a fair assessment. The duration for the collection of articles covered a span of four months during the lockdown. New York Times started reporting about the lockdown from 7 March to 13 June 2020, which covered a total of 429 articles. Vice News on the other hand started a few days earlier on 3 March and ended on 12 June 2020 with a total of 111 articles. The overall total of the articles accumulated for this research was 540 articles.

\subsection{Data Collection}

The data collection process was simplified to promote efficiency. The single tool used was a table consisting of the following headings: "date, article title with hyperlink, summary/information" and "authority". Separate shared documents of the same tables were made for alternative and mainstream articles. Collected articles were chronologically ordered based on the date of publication.

\subsection{Categorization}

In this stage of the process, its main goal was to create categories based on homogenous characteristics that each article provided (Bengtsson, 2016). The criteria to formulate a category was simple: if a topic was written about four or more times in the articles then its own category was made. 


\subsection{Data Analysis}

The articles were analyzed based on four main criteria in order to begin drawing conclusions from the research. Between fifteen categories and the high volume of journals, there are simply too many points of discussion. Furthermore, discussing fewer, more relevant categories kept the study focused.

\subsection{Pros and Cons of Qualitative Content Analysis}

A qualitative content analysis has several advantages. The primary advantage being the ability to quantify and provide qualitative conclusions on the data. Secondly, it provides a large overview because a large amount of data can be included in the research. Categorization links to the second point, due to the large volume of articles, categories could be formed which inherently gave an overview of the research. On the other hand, a qualitative content analysis has drawbacks. Without question, it is time consuming and due to the large volume, is subject to errors in the analysis. Secondly, it does not follow a theoretical approach, which can reduce the quality of theoretical interpretations.

\section{Findings and Discussion}

\subsection{Number of Deaths}

The article chosen to represent this topic for New York Times is "Coronavirus in N.Y.: Toll Soars to Nearly 3,000 as State Pleads for Aid". For the Vice News Channel, the chosen article is: "VICE - New York's Coronavirus Death Toll Just Spiked, And the Worst Is Yet to Come". The headline for the New York Times article stated numerical values such as "Nearly 3000" whereas the headline for Vice made a prediction that "The Worst is Yet to Come". However, Vice did not mention the exact number of deaths in the headline. The mainstream article provides more sources and quotes from authority figures compared to the alternative article.

New York Times gathered information provided from authoritative figures such as Andrew Cuomo the 56th Governor of New York, hospital officials, White House coordinators, and Republican officials, whereas the Vice article only uses one source, Andrew Cuomo. Vice News Channel and New York Times have the same story angle which focuses on statistics of cases, deaths, and the shortage of medical equipment like ventilators. Nevertheless, New York Times provided more proof of statements compared to Vice News Channel. The New York Times article had more quotes from the authorities and contained fewer opinions from journalists. The articles used visual images that had front liners such as healthcare workers and policemen. Vice's article only contained one image whereas The New York Times had four. The image provided by Vice also had no captions whereas every picture in The New York Times had a caption, describing the image.

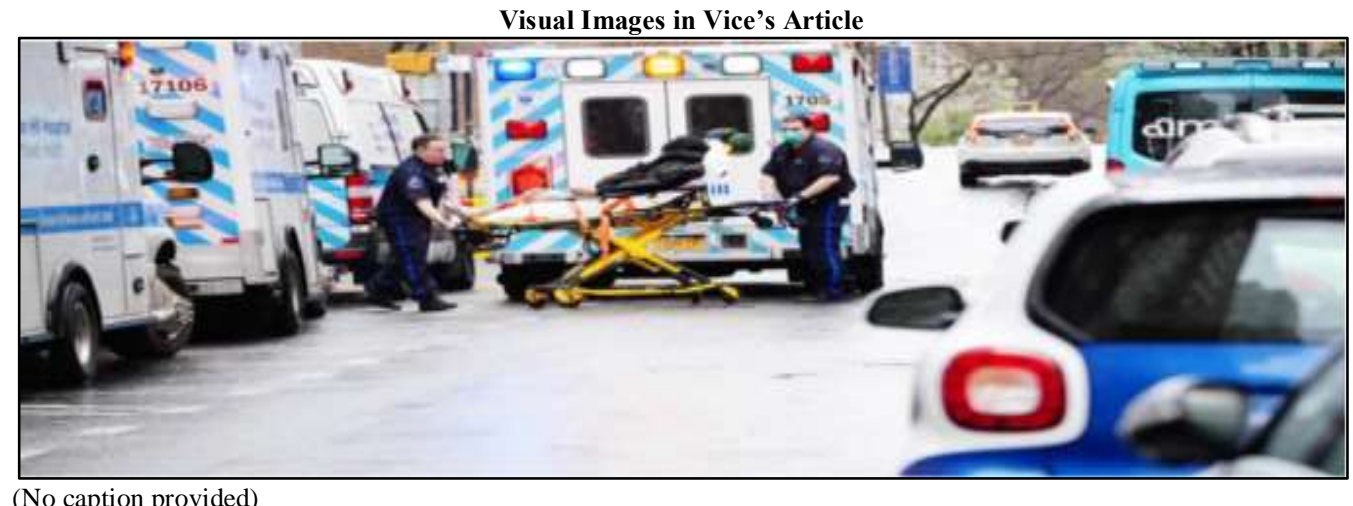

(No caption provided)

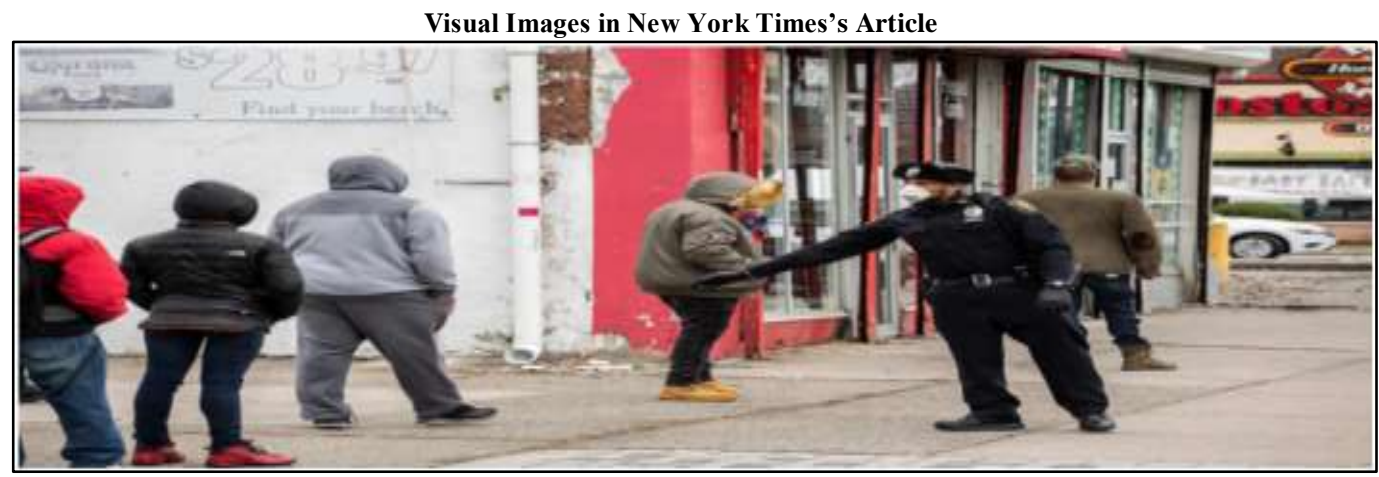

Enforcing social-distancing rules outside a check-cashing business in East Orange, N.J., on Friday Credit-Bryan Anselm for The New York Times 


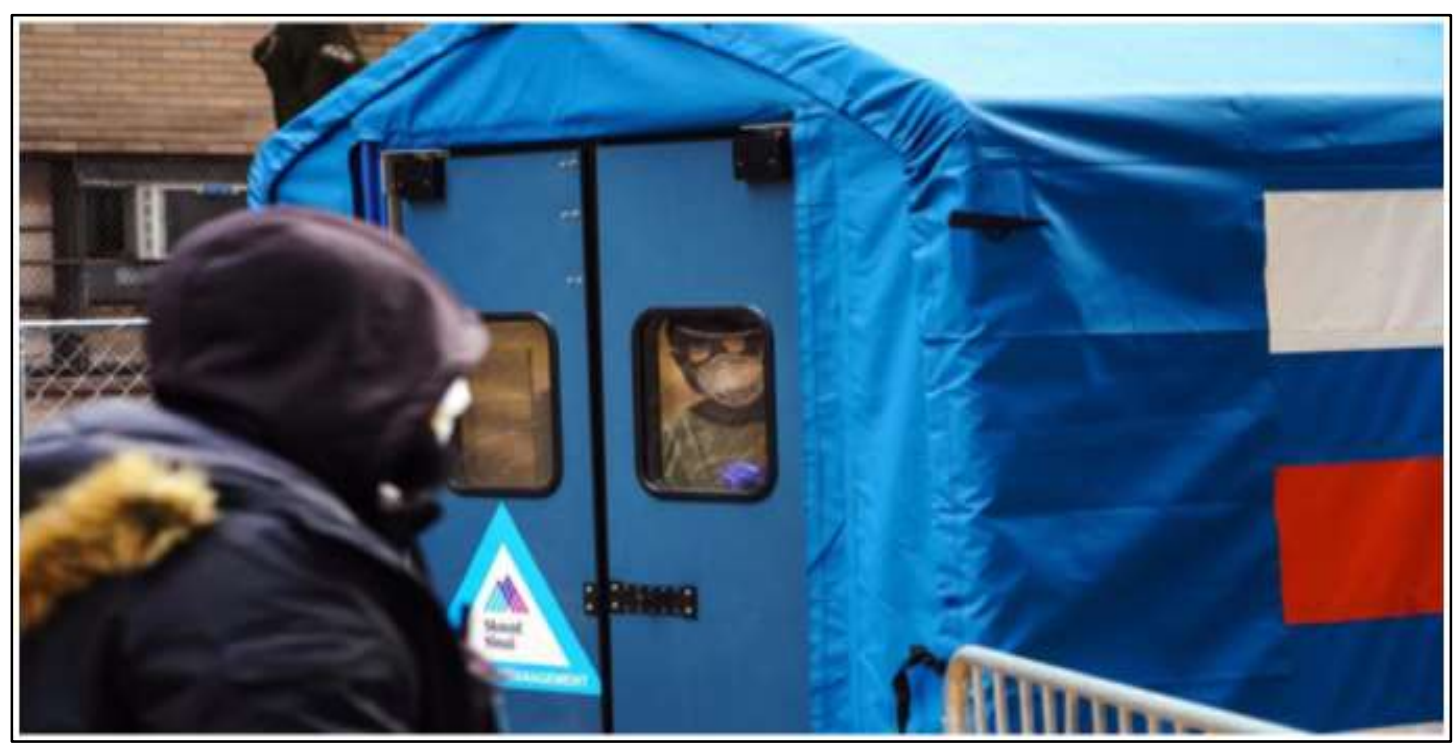

Screening tent outside of Mount Sinai Hospital West in Manhattan Credit - Chang W. Lee forThe New York Times

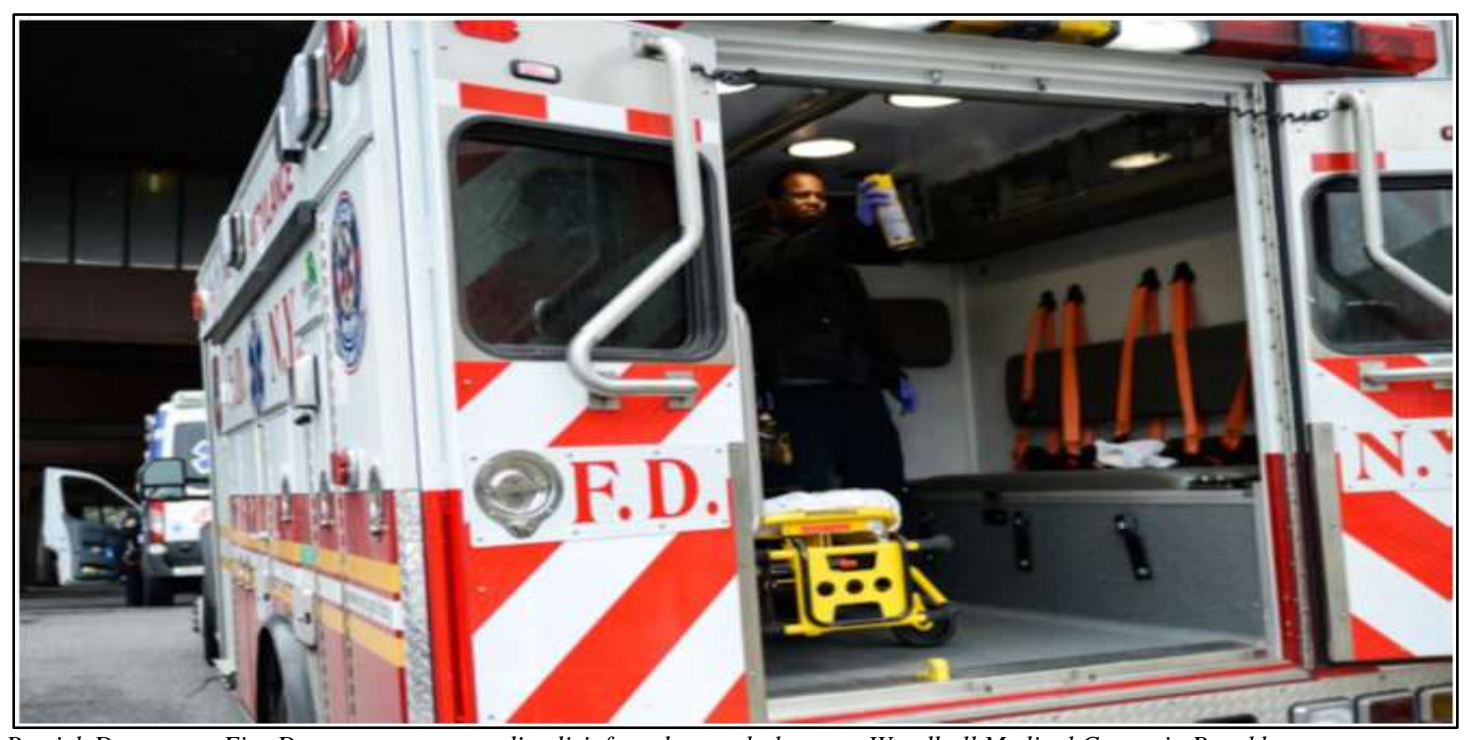

Patrick Donowa, a Fire Department paramedic, disinfected an ambulance at Woodhull Medical Center in Brooklyn. Credit - Marian Carrasquero for The New York Times

\subsection{Loss of Jobs/Unemployment}

Vice News Channel and New York Times stated the pandemic had affected the unemployment rates in New York and The United States in general, however both news channels had slight differences in presenting the issue. The article chosen to represent Vice News Channel was Coronavirus Has Put More Than 16 Million People Out of Work in Just 3 Weeks and for New York Times is, 'I Cry Night and Day': How It Took One Woman 8 Weeks to Get Unemployment. First, Vice News Channel's headline provided a background context in the headline itself on what has caused 16 million people to be put out of work. However, for the New York Times article, it did not provide a context or a reason, which might cause ambiguity, leaving readers confused and curious which might be a tactic probably used to gain readership and news circulation.

The story angle in New York Times was one sided as the article only uses one source, which is Nadine Josephs, the unemployed woman. On the other hand, multiple sources were used in Vice's article as it is based on facts and statistics such as data from the Labor Department and quotes from the National Multifamily Housing Council. The story angle for both news channels were also different when portraying this issue; multiple articles from New York Times on unemployment are opinion pieces or stories from one individual whereas Vice focused on the unemployment rate in general. Even so, stories from unemployed individuals were not completely ignored by Vice. The news channel wrote an article interviewing ten unemployed individuals and compiled it into one piece instead of focusing on one individual only. Based on the articles, the mainstream news channel did not give actual numbers of the unemployment rate and tend to provide sensationalized life stories of an individual to gain human interest whereas the alternative provides factual data to prove a point. A picture of Nadine Josephs was also included in the New York Times article, whereas Vice used an image for decorative purposes. 
Visual Image provided by The New Times's Article

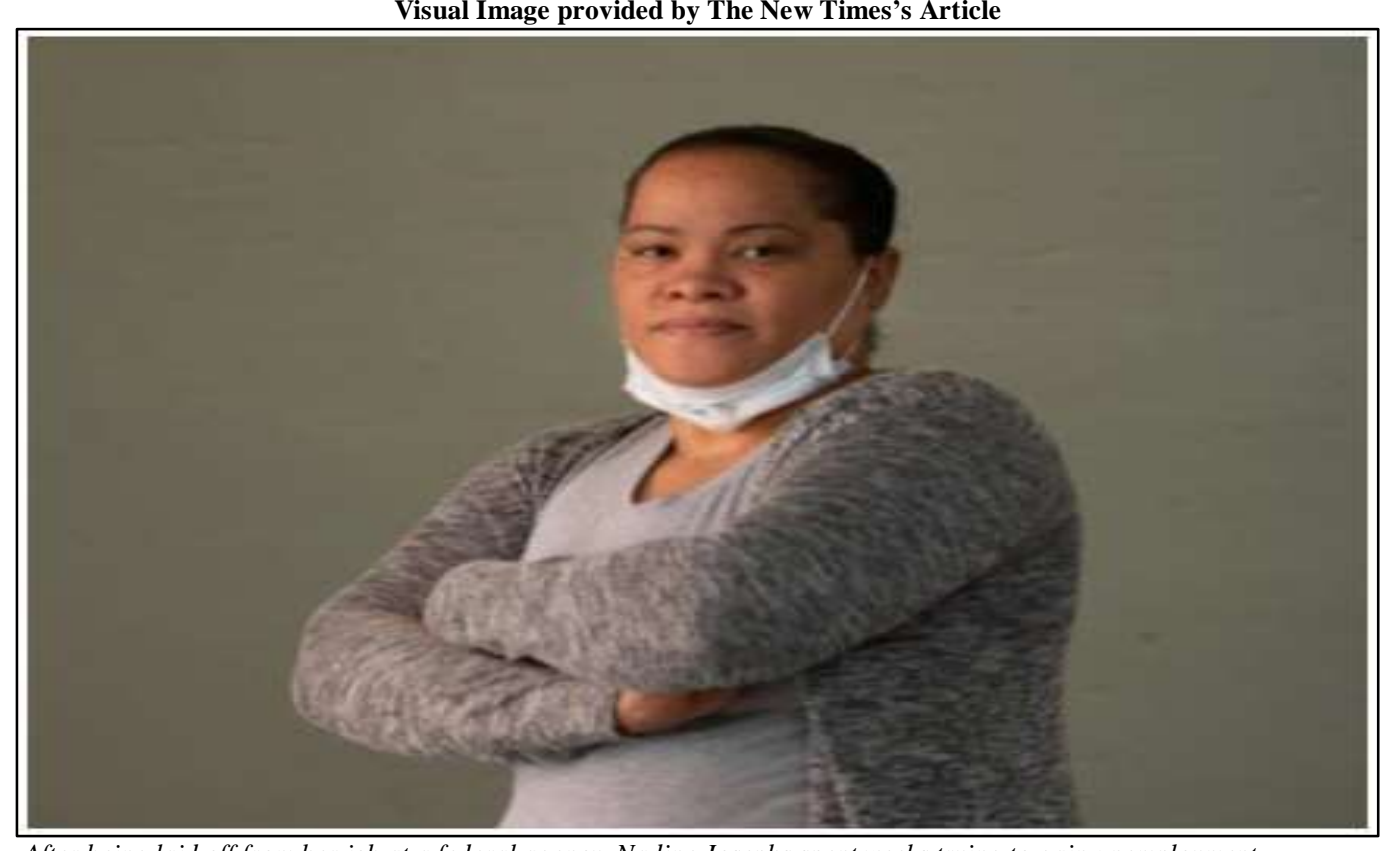

After being laid off from her job at a federal agency, Nadine Josephs spent weeks trying to gain unemployment benefits.

Credit - James Estrin for The New York Times

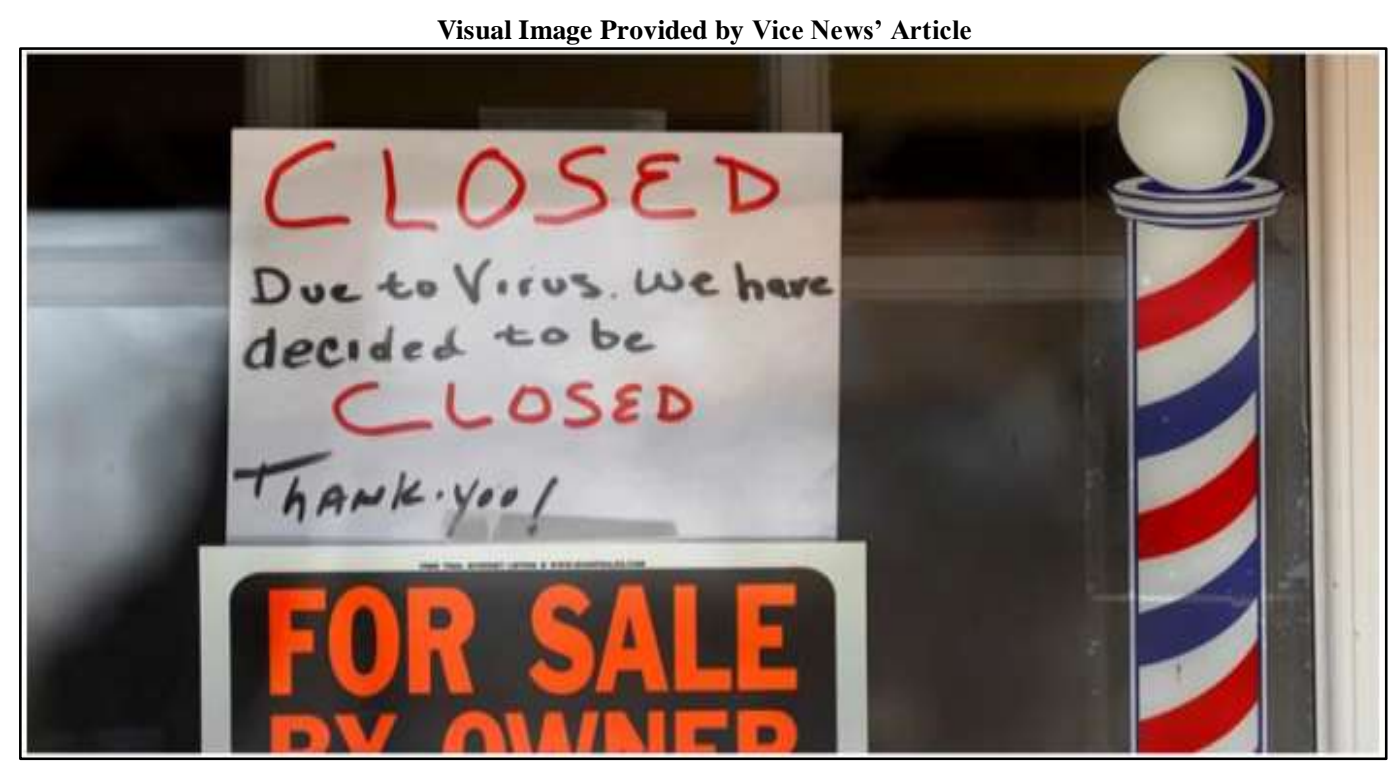

(No caption provided)

\subsection{Virus Wide Spread in Jails}

The coronavirus epidemic at Rikers Island Jail in New York City was a subject matter addressed within articles by the mainstream and alternative news stations, The New York Times and Vice News respectively. 'A Storm Is Coming': Fears of an Inmate Epidemic as the Virus Spreads in the Jails reflects the literature of The New York Times, whereas, A Rikers Guard Tested Positive for Coronavirus as New York City Considers Releasing Some Inmates reflects the literature of Vice News. Accordingly, through explications, we depict the headline for The New York Times to be ambiguous and indistinct due to the statement, 'A Storm is Coming'. Furthermore, headline representation omits significant discussions reviewed in the news piece e.g., the release of inmates. Contrastingly, the headline for the alternative station is accurately depicted and encompasses all discussions reviewed in the piece.

The New York Times cited and sourced numerous authoritative figures, for instance, public defenders, New York's Mayor Bill de Blasio, district attorneys, Board of Corrections and Governor Andrew Cuomo. Additionally, the mainstream station cited and sourced inmates and Rikers staff members. In comparison to the alternative source, the reporter cited a spokeswoman working for Mayor Blasio's office, the union representing corrections officers in New York City and the Board of Corrections - all of whom represent the same direction.

Conclusively, regarding the dissimilarities concerning the sources utilized by both news stations, the mainstream offers more sources and citations than the alternative. Moreover, the mainstream offers sources from nonauthoritative figures to provide the audience with a balanced article whilst the alternative omits.

The story angle and perspective, similar to balance, is portrayed equally with statements from opposing parties within the narrative of the article. Commentary from the reporters, Jan Ransom and Alan Feuer was undetected. By comparison, the alternative story angle and perspective focused on representing one party without the other party, 
counteracting the statements and sources. Two accounts of partisan narrative and biases occurred within the literature. For instance, the reporter, Tess Owen, utilized the adjective "notorious" to characterize Rikers Island, and stated in her commentary Rikers Island has a "long- standing reputation for neglect, violence, and abuse". The visual images applied within the narrative utilized by The New York Times depicted conditions at Rikers Island. Image 1 is captured outside at the entrance of the jail complex, similar to image 2. However, image 3 displays the conditions inside the jail.

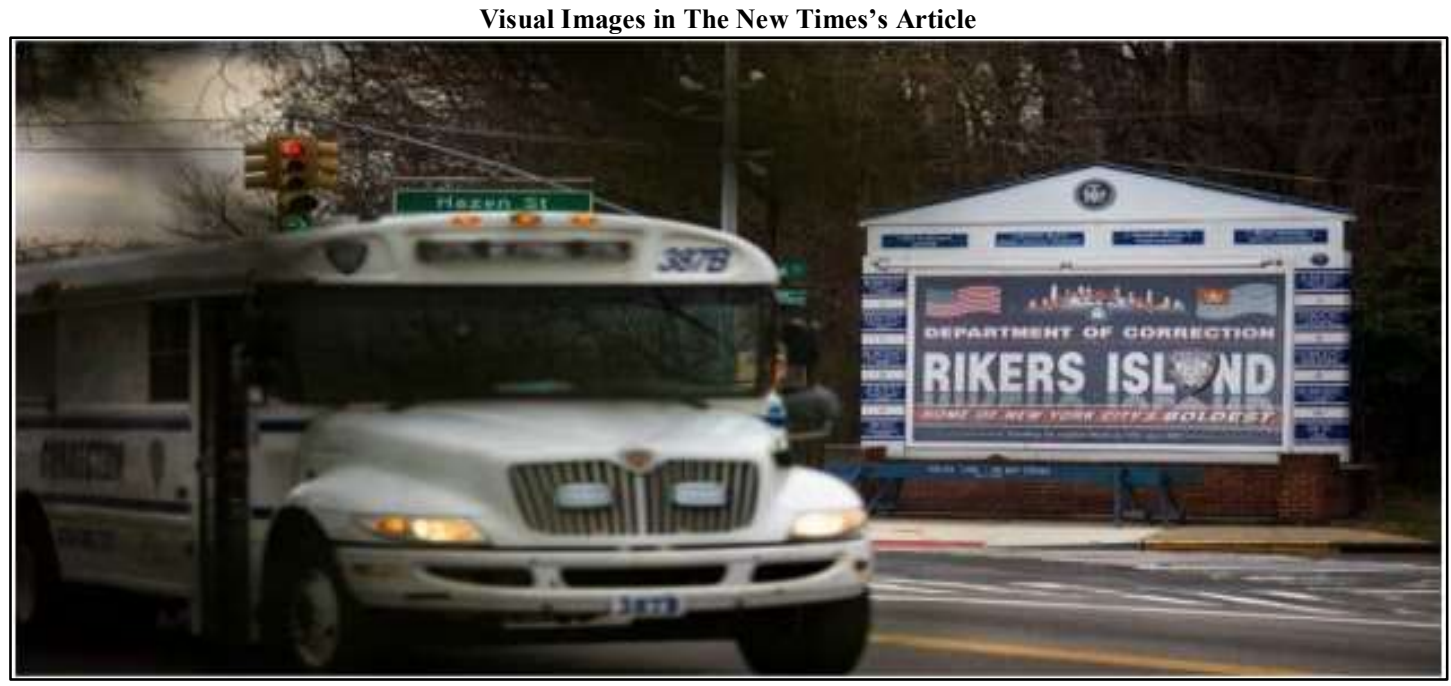

The entrance to Rikers Island, the New York City jail complex.

Credit - Dave Sanders for The New York Times

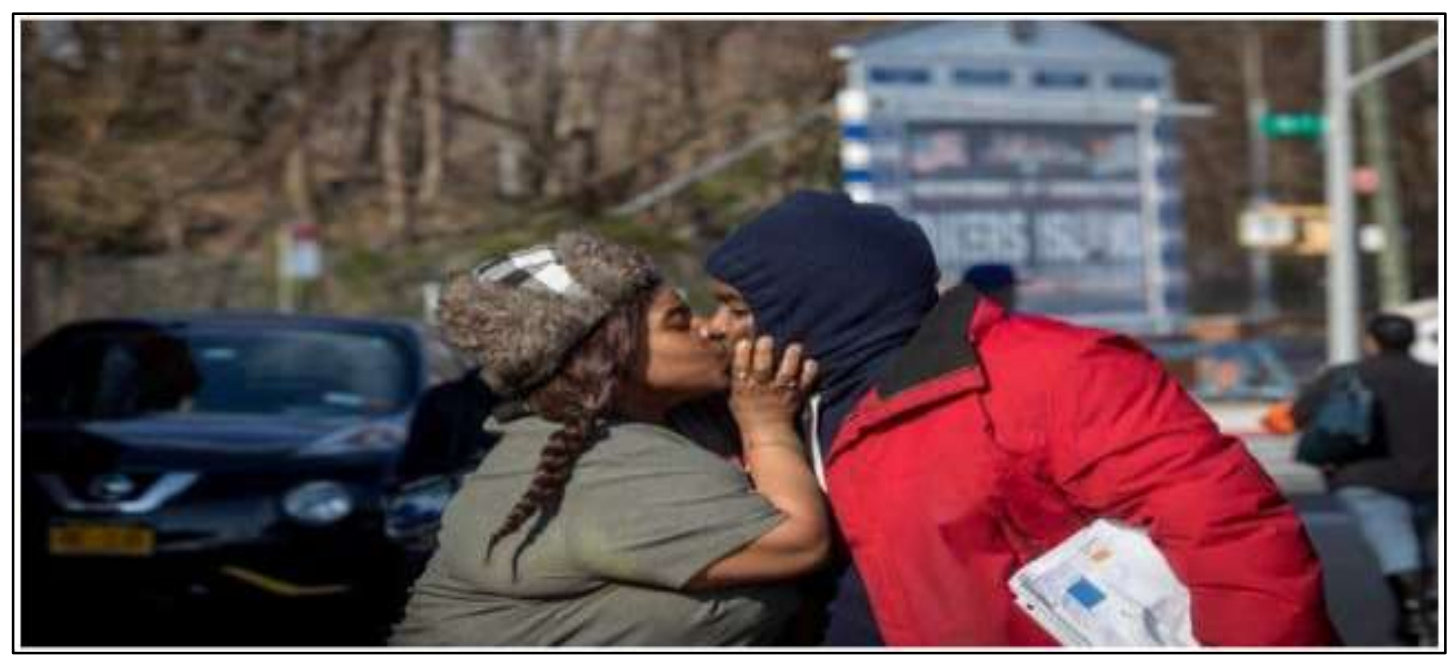

Rayshad Jackson, right, was greeted by his wife, Courtney, after he was released Friday

Mr. Jackson said his release was expedited because he has asthma and another inmate tested positive for the coronavirus. Credit - Dave Sanders for The New York Times

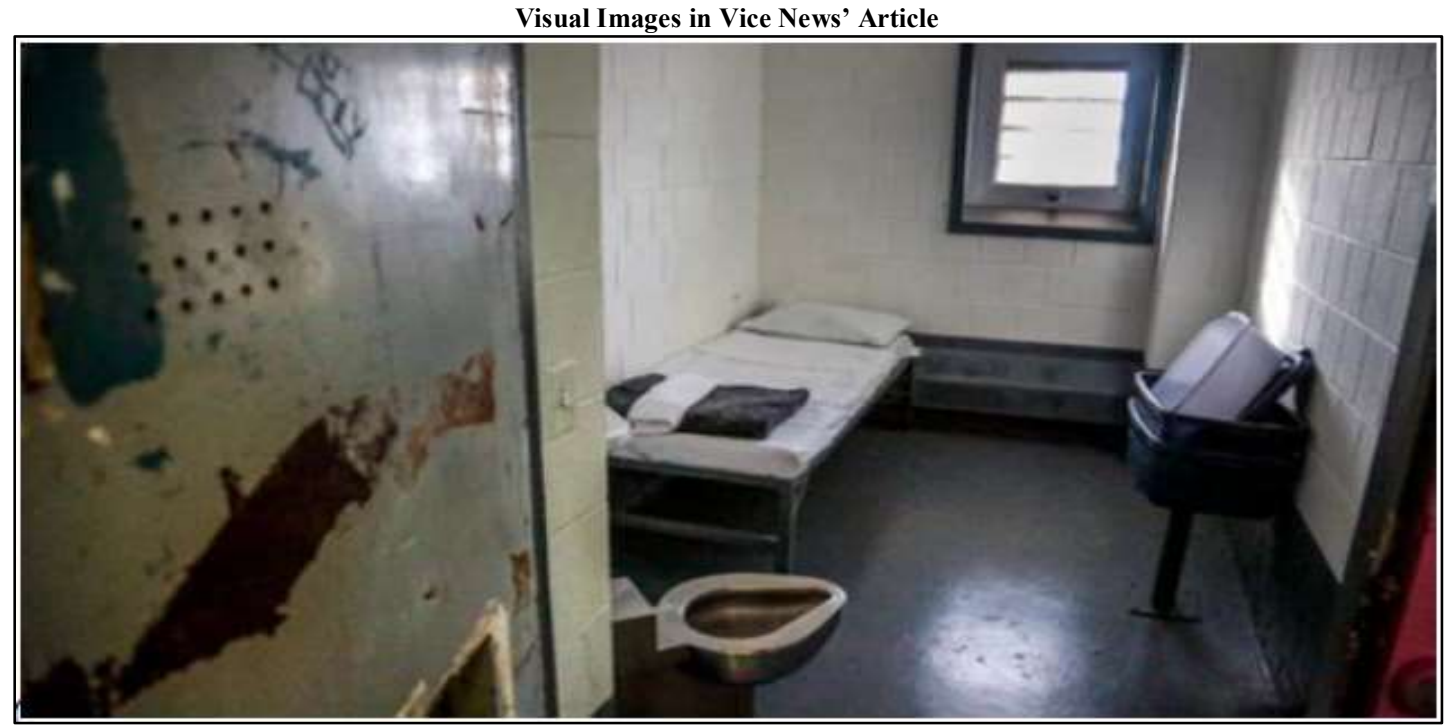

No caption provided) 


\subsection{Coronavirus Updates}

Vice news released the piece, The Rate of Coronavirus Cases Is Doubling Every 3 Days in New York State was in stark contrast to The New York Times's, How Cuomo, Once on Sidelines, Became the Politician of the Moment. Although both articles' subject matter was equivalent, the headline representation for the alternative was misleading of the matter discussed. Portrayal of the mainstream headline in regard to the literature is, however, accurate. Vice News sources the governor, whereas The New York Times sources the governor, Vice President Mike Pence, New York Democrat Grace Meng and Donald Trump.

A similarity demonstrated between both stations stated no non-authoritative statements and sources cited. Accordingly, as Vice News sources Governor Cuomo, the narrative of the literature was partisan without balance. For instance, as stated in the alternative article, "During the press conference, Cuomo repeatedly slammed the federal government for not doing enough to help New York treat Covid-19 patients", perspective of the federal government was not accounted for. Contrastingly, The New York Times incorporated balance within the literature as shown by the following statements, "You (federal government) pick the 26,000 people who are going to die because you only sent 400 ventilators." and the counteract, "Vice President Mike Pence said 2,000 ventilators were being sent to New York, with a promise of 2,000 more on Wednesday."

Articulation of Vice News revealed negative signs of commentary. However, commentary was present within The New York Times as reporters: McKinley and Goldmacher, included personal opinionated statements regarding Governor Cuomo e.g., "too much of a pragmatist for his party's progressive wing, too self-focused for party leaders and too brusque for nearly everyone."

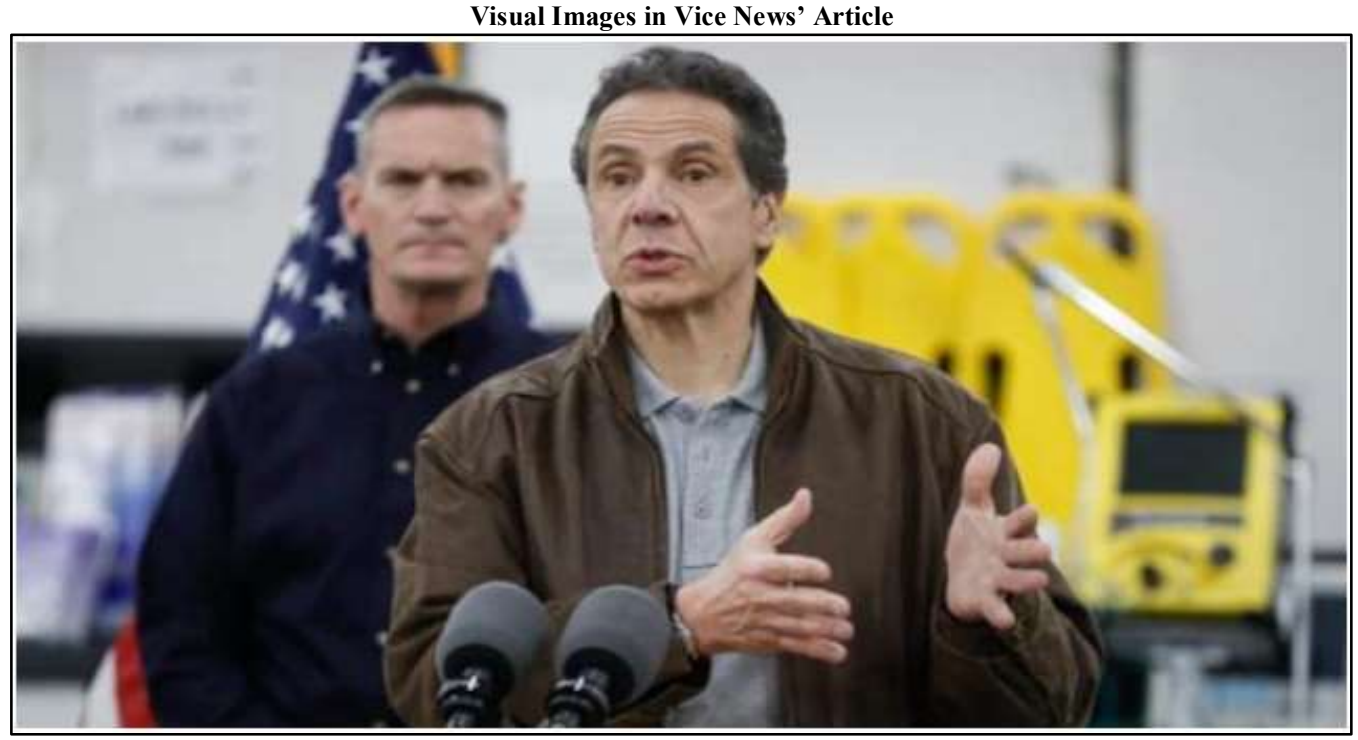

(No caption provided)

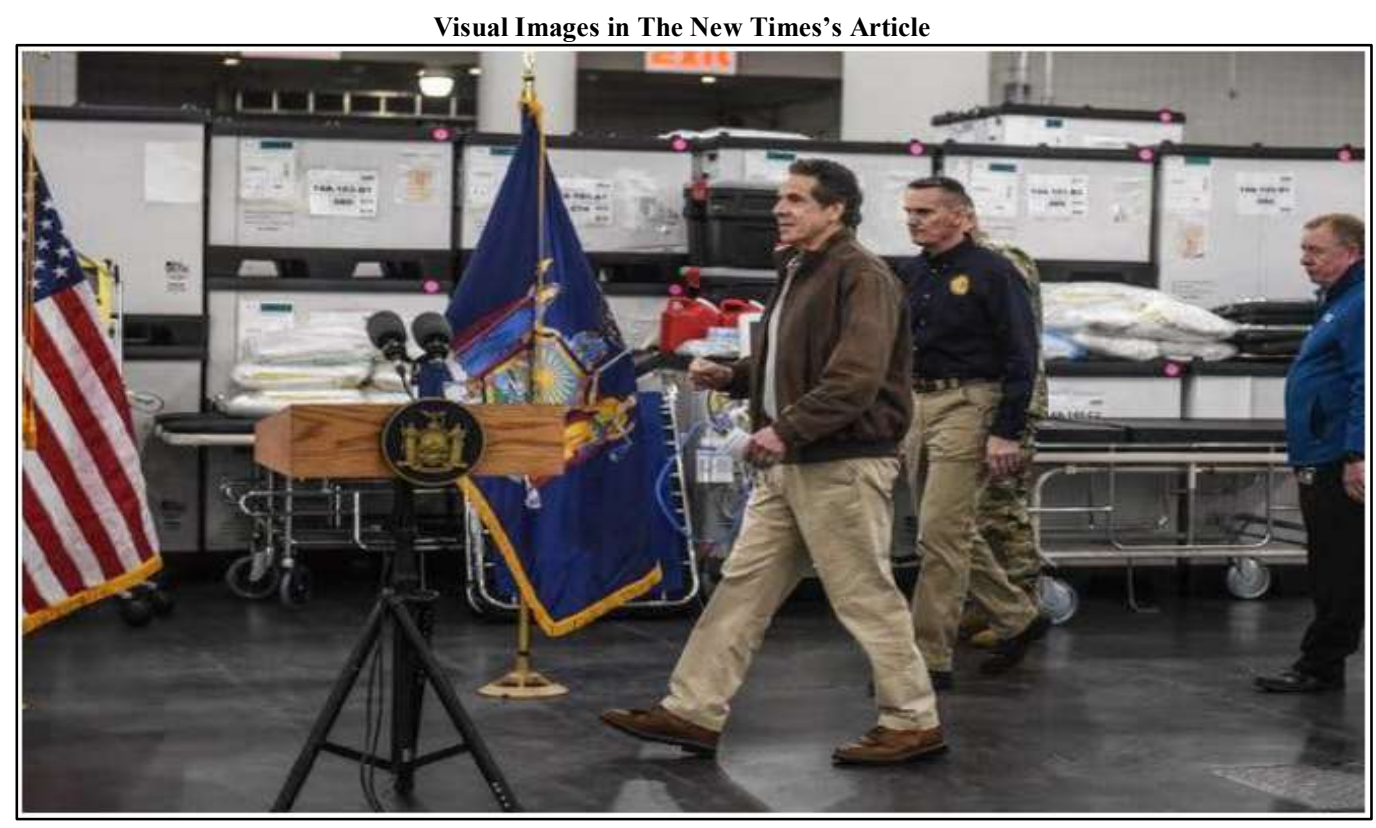

In recent days, Gov. Andrew M. Cuomo has used the Javits Center, which is being converted into hospital space, as a backdrop for his briefings.

Credit - Stephanie Keith for The New York Times 


\subsection{Homeless Individuals}

Vice news reported, "Coronavirus Is Devastating Homeless Shelters across the Country" whereas, the New York Times reported, “It's a Time Bomb': 23 Dies as Virus Hits Packed Homeless Shelters”. Headlines for the alternative, while accurately representing the narrative, was vague in mentioning the capacity and manner coronavirus was "devastating homeless shelters". In comparison, the mainstream literature captures the audience's attention with, "It's a Time Bomb". Additionally, statistic was mentioned to illustrate the full article. Vice News did not incorporate statements from authoritative individuals, however, they cited doctors, nurses, and shelter providers. Statistical data was compiled primarily by "a limited VICE News analysis". Contrastingly, sources in the New York Times included statements from homeless individuals, Mayor Bill de Blasio, Stephen Mott (Chief of staff for HELP USA) and Derek Jackson (Director of Law Enforcement).

The story angle pursued by Vice News depicted a reporter's analysis, thereby the balance of the article was present. Accordingly, language is formal, and information was presented without misinterpretation. Similar balance was portrayed at the New York Times as they interviewed and embedded statements from non-authoritative and authoritative individuals. However, Derek Jackson's statement, "the city was slow to provide masks, gloves and other personal protection equipment to the officers" it was as the sole occasion in the mainstream article where the narrative was unbalanced, no statements by city officials were included to counteract the said statement. Neutrality was exhibited as the news used to inform the audience was precise without commentary. Visual images utilized by both news stations depict homeless individuals.

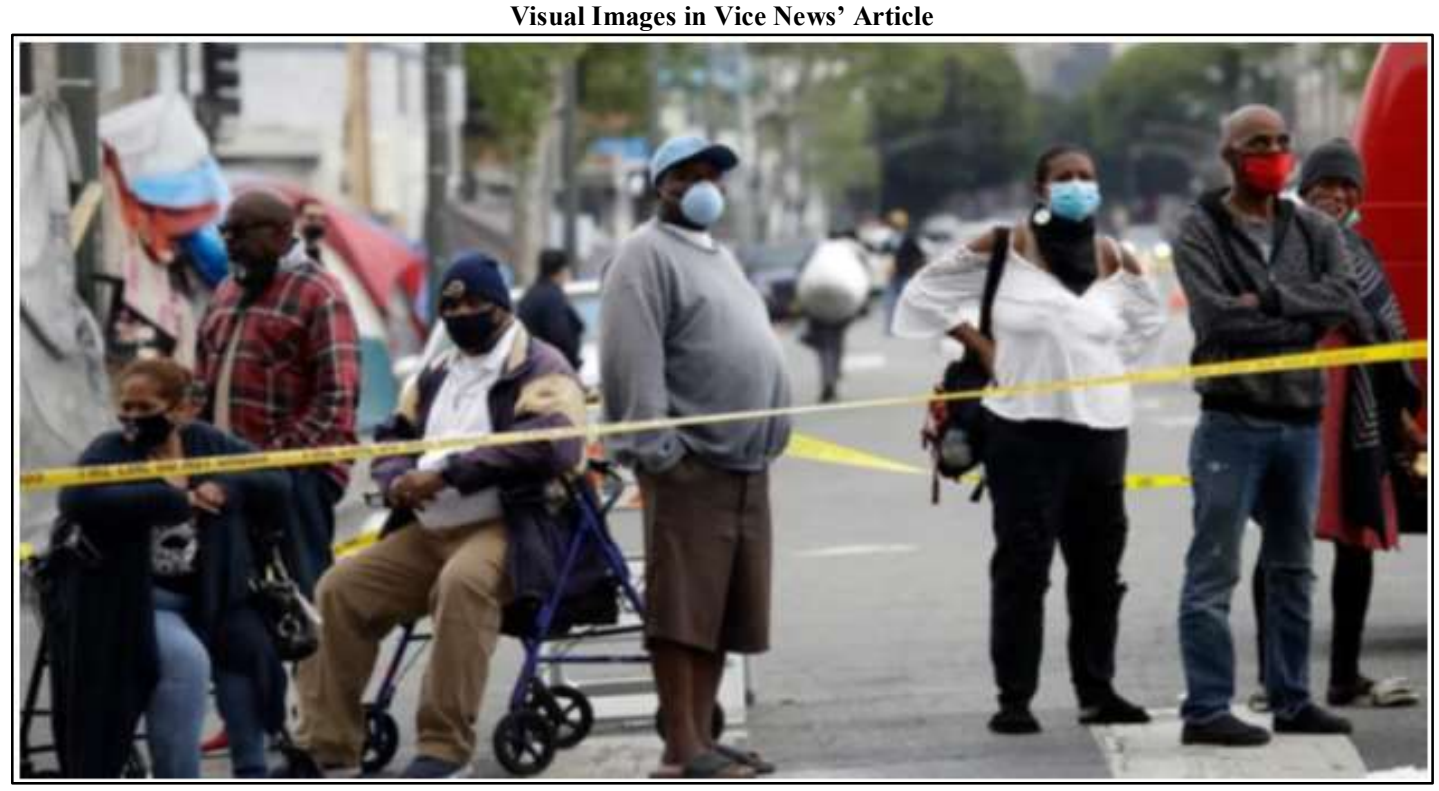

(No caption provided)

Visual Images in The New Times's Article

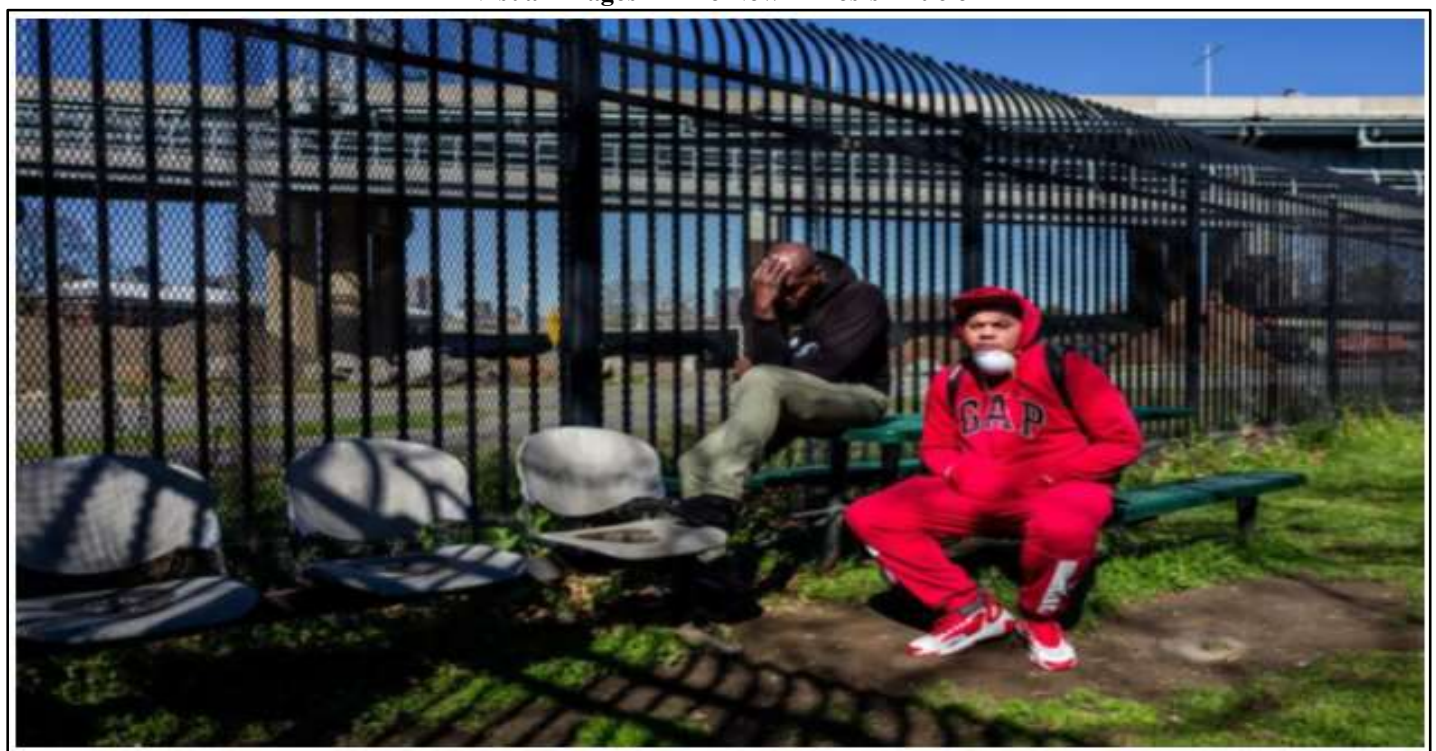

Alfonzo Forney, left, and Roberto Mangual are staying in a homeless shelter where a resident recently returned despite having the virus. "We should have a fair chance to protect ourselves," Mr. Mangual said. Credit - Jonah Markowitz for The New York Times 


\subsection{Lockdown}

The alternative headline, "No One Fled Harder from Coronavirus than New York's Wealthy" employs "harder" to insinuate wealthy New Yorker's abandoning their less privileged members. Contrastingly, the mainstream headline, "Did New Yorkers Who Fled to Second Homes Bring the Virus?" does not implicate as such. Statements from Vice News were outsourced from the New York Times by non-authoritative figures. A statistical analysis embedded within the article was cited to STAT's COVID-19 tracker, whilst another statistic was not sourced accordingly. Similarly, the New York Times cited an external research concluded by Kinsa. However, statements within the mainstream article were primary and extracted from authoritative figures; Shaun Groden, Green County Administrator, and Marynia Kolak, Assistant Director for health at the University of Chicago.

The perspective Vice chose was unbalanced as no statements were used to counteract the versions of events. To illustrate, "The population in some of New York's wealthiest neighborhoods decreased by more than $40 \%$ between March and the beginning of May" and "uneven distribution of risk, and the unfairness of having to work to provide services to people who are wealthy enough" were targeted to guilt those who abandoned the city. The New York Times pursued an identical unbalanced approach. Kolak and Bryan Polite's statements, "At a county level, these areas were already flagged as hot spots", and "Those people (New Yorkers) were selfish, and we have to deal with the ramifications of their actions" similarly target New Yorkers who aside from abandoning the city, brought the coronavirus to its exurbs.

A stark difference in literature from the news stations was commentary; while the New York Times omits the reporter's analysis and commentary, Vice exhibits such remarks. Vice's reporter expressed his opinion on an article published by the New York Times, stating it was ridiculed for "tone deafness". The images shown below depict Vice's sole pedestrian wearing a mask, walking through the empty streets. Whereas, the New York Time's image depicts a mask-less couple and family, while they stroll outside the city's exurb.

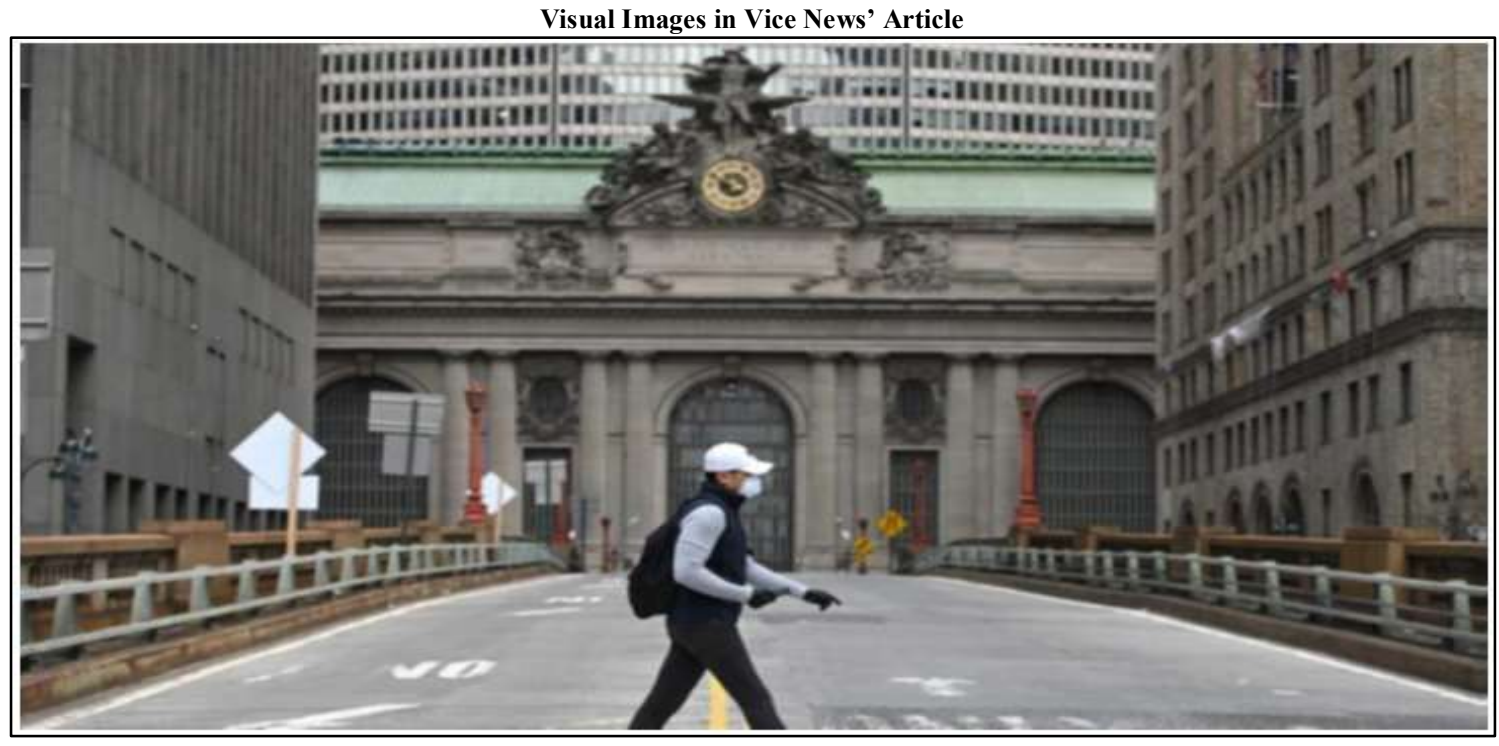

(No caption provided)

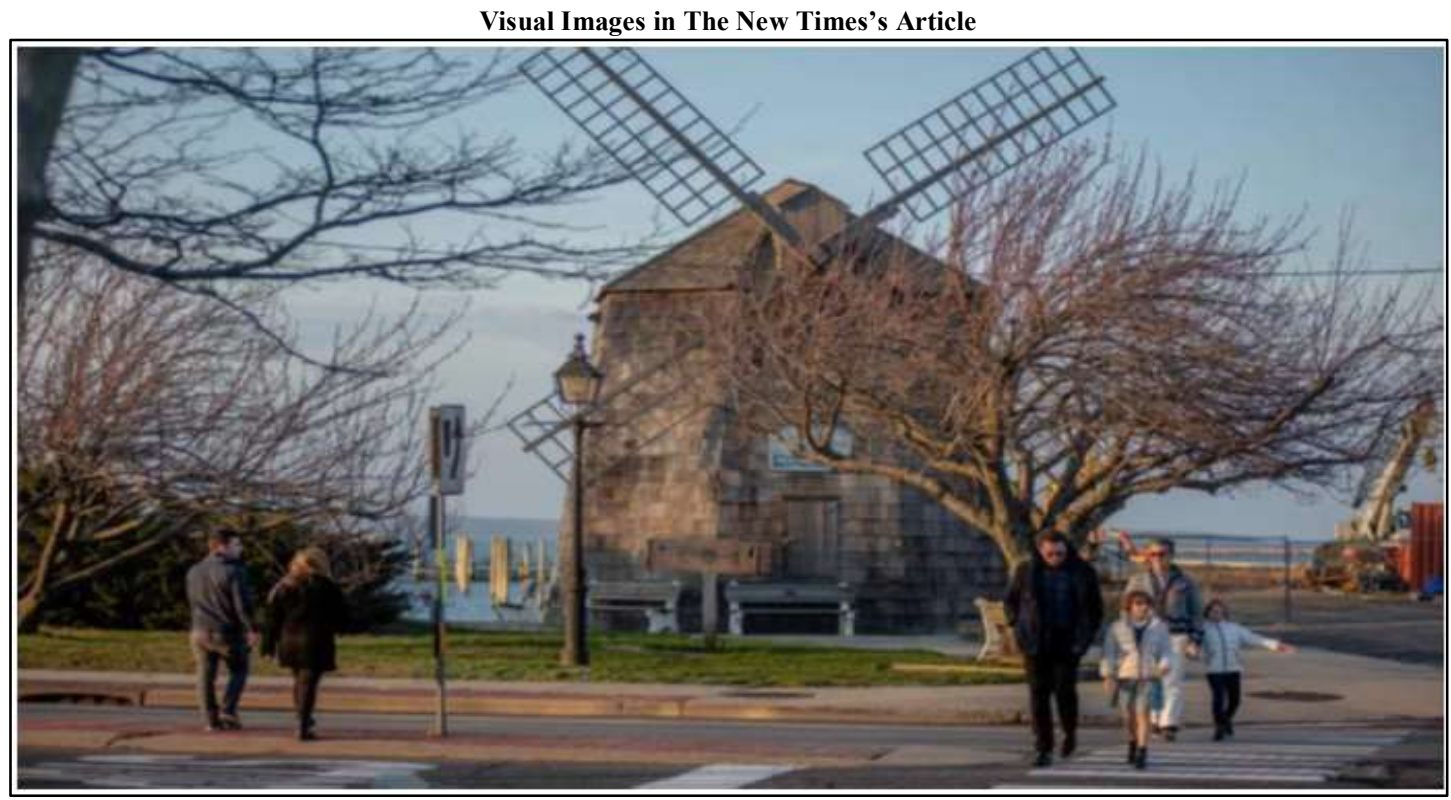

Businesses in the Hamptons are trying to keep up with a sudden influx of visitors.

Credit-Johnny Milano for the New York Times 


\subsection{Healthcare}

The chosen article to represent Vice on healthcare was VICE - New York Plans to Convert Javits Center into a Field Hospital as Coronavirus Cases Jump by Thousands Overnight and as for New York Times was N.Y. Weighs Four Temporary Hospitals Sites, Including Javits Center. The headline for Vice only mentions Javits Center, despite other locations being converted into temporary hospitals. As Javits Centre was well-known, it is important to include the name to capture the audience's attention. To compare, New York Times's headline expresses that other locations were being converted, including Javits Centre. Vice's headline also states the coronavirus cases had jumped by thousands overnight, providing some context. The sources used by Vice cites Governor Cuomo, making it entirely based on Governor Cuomo's quotes, whereas New York Times cites Cuomo, doctors at Lincoln Medical and Mental Health Centre and the Trump Administration. The article included statements from authoritative figures, establishing credibility.

The content of Vice's article strayed away from the main topic as it focused on the number of Covid-19 cases and shortage of medical supplies whereas The New York Times fixated on the issue. Vice's article did not contain statements stating that other locations were being converted into temporary hospitals. Contrastingly, the mainstream article said that officials had visited more than a dozen locations before deciding on the four sites. The content of New York Times was similar to Vice, however, the article has a "What You Need To Know" section containing a brief summary on current updates to provide background information for readers. The image used by Vice in the article features citizens lining up to buy tamales, irrelevant to the topic. Vice, on the other hand included a picture of a woman holding a pole with a tissue, symbolizing the fear of New Yorkers.

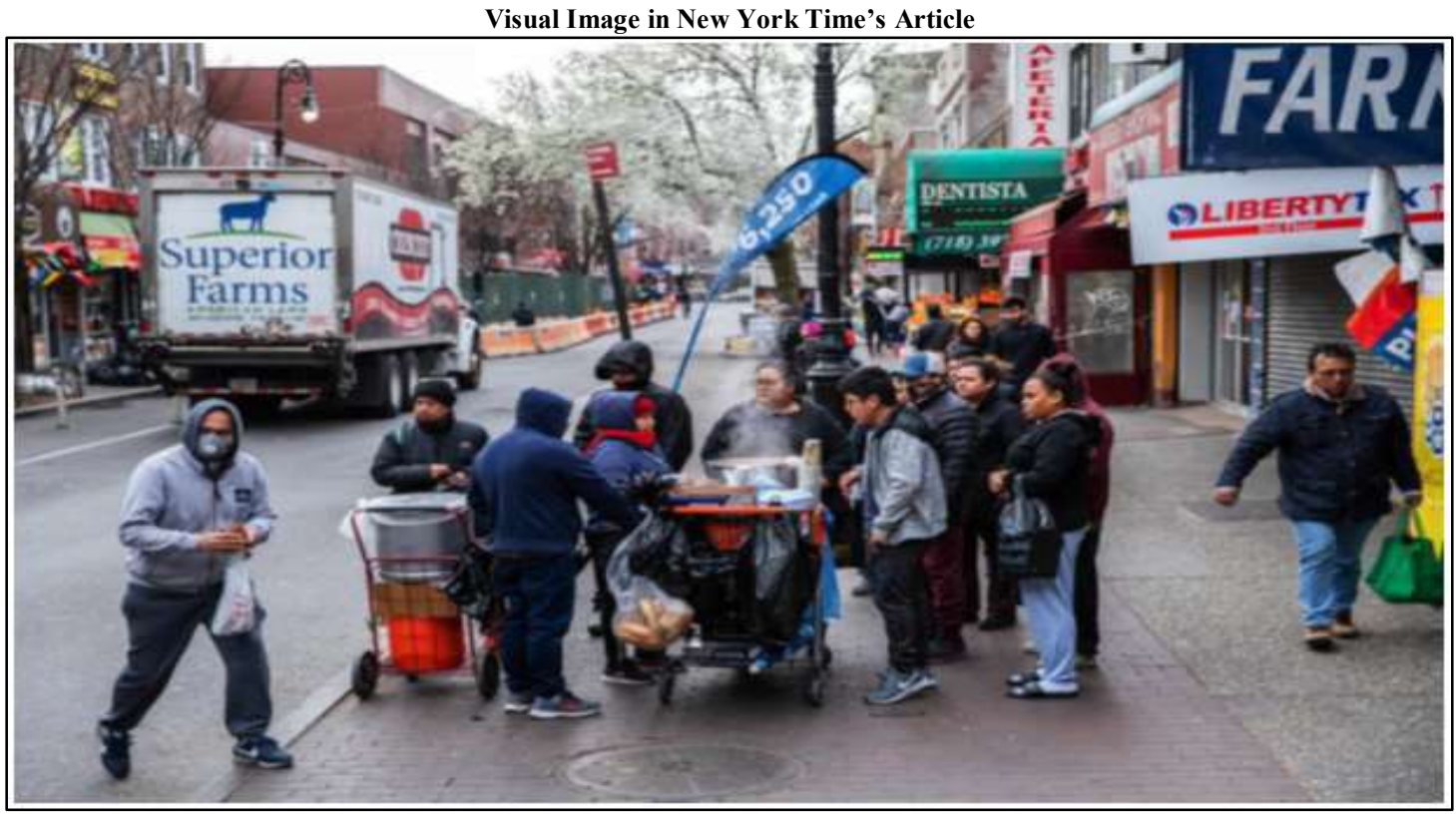

People in the Jackson Heights neighborhood of Queens lined up to buy tamales and coffee from a street vendor near Roosevelt Avenue on Saturday. Credit - Juan Arredondo for the New York Times

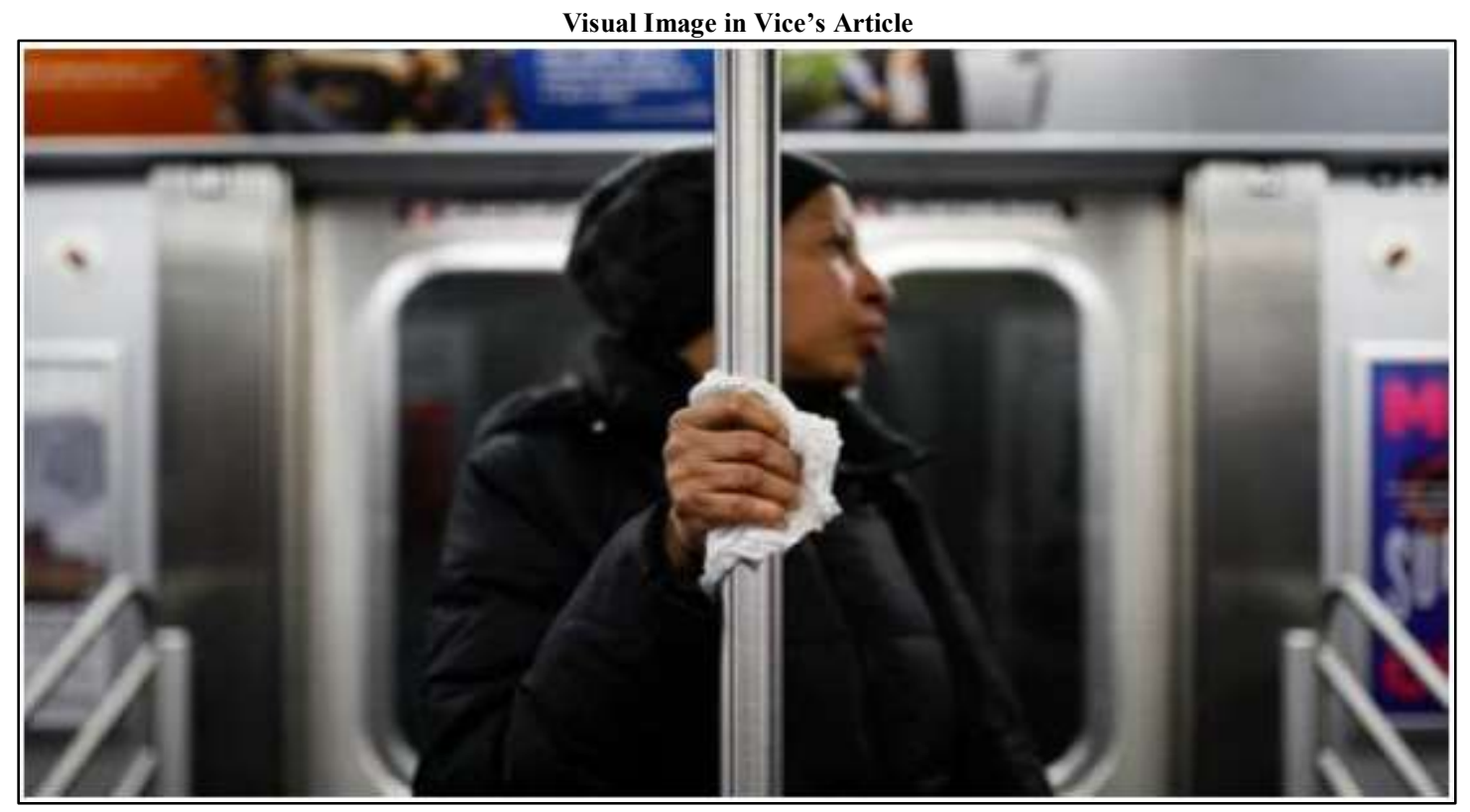

(No caption provided) 


\subsection{Nursing Homes}

Vice's article which is An Entire Nursing Home Is Being Relocated After at Least 10 Confirmed Coronavirus Cases and New York Times's article Coronavirus on Long Island: 6 Die in Outbreak at Retirement Community were released on the same date, regarding St. Joseph's Senior Home coronavirus cluster. The words "at least" were used in Vice's headline therefore, a definite number of cases was not specified. Death counts of the cases were not clarified, leaving out an important aspect of the article. The New York Times headline however was an accurate representation of the news. The angled approach by Vice was neutral and was an analysis of the occurrence. Statements from the nursing home residents and primary takers were not included in the article.

The New York Times article was written in a timeline-like format from when the nursing home outbreak began until the current update. Statements from the nursing home residents and authoritative figures were included in the article, therefore minimal bias was present. For example, "The sisters told us on Friday that 12 of their employees were home, feeling ill with respiratory symptoms, "A quote by New Jersey health Commissioner Judith Persichili, was used as a secondary source. Nonetheless, the article stated a significant figure, the Catholic Healthcare facility "did not respond immediately" after Vice News requested a commentary on the issue. The usage of the words "did not respond immediately" might cause confusion as the article did not mention whether they provided a response. Next, the Vice article cited other news stations such as Komo News and A Daily Voice for statistics such as the number of Covid-19 cases. New York Times, however, did not reference other news sites but included a commentary from a senior citizen that Vice News lacked. Visual images used by both new sites were similar, featuring healthcare workers helping the bedridden senior citizens.

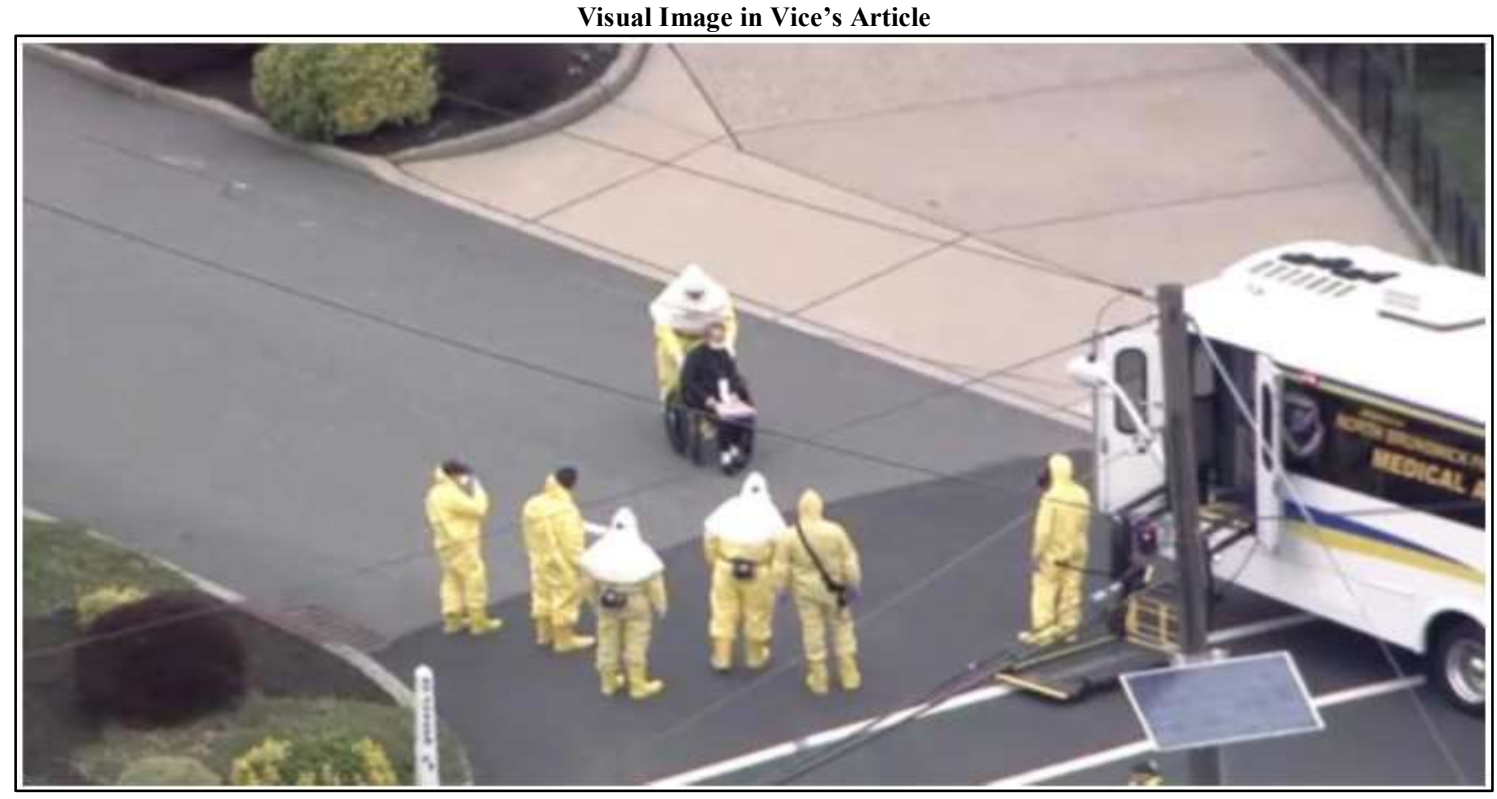

(No caption provided)

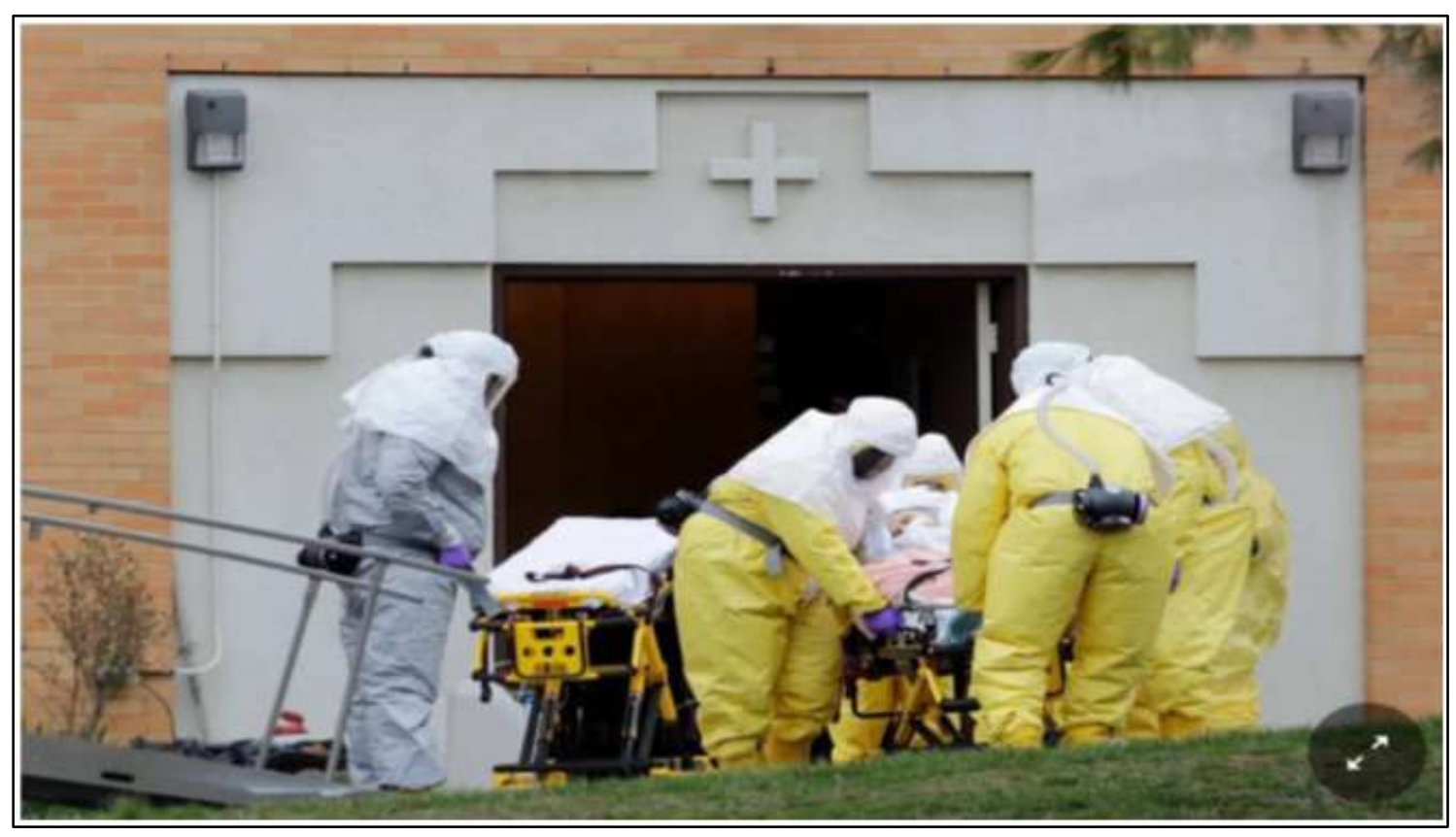

Facilities for older adults are especially vulnerable to infection. At St. Joseph's Senior Home in

Woodbridge, N.J., at least 24 residents tested positive for the virus.

Credit-Seth Wenig/Associated Press 


\section{Conclusion}

Conclusively, this analysis is based on four criteria's: headlines, sources, language, and visual images. A summary of the headline regarding the alternative resultantly informs us that Vice incorporates a majority of vague, misleading titles. Contrastingly, the New York Times incorporates a majority of accurate and informative titles. Dissimilarities occur regarding the sources whereby a majority of the citations are composed of a sole informant for Vice News and multiple sources for the New York Times; authoritative and non-authoritative.

Furthermore, the language utilized by both news stations were formal and informative. However, Vice News reporters incorporated increased commentary and opinionated statements. Both stations included visual images. However, Vice News did not provide captions, nor did they credit their image to the owner while the New York Times included both. A theory that suits this paper is agenda setting theory. With the current study the type of agenda theory that is most aligned is the media-agenda setting theory. Media-agenda setting is when the media decides what current topics are considered most important for the issues at hand (Alvernia, 2019).

Framing is a concept that media outlets will use to help readers follow a certain line of thought. The reader will assume that they came by a conclusion naturally or by themselves, when in reality they were following a particular line of thought via conveniently placed facts or information by media outlets (Theory, 2014). Framing is apparent by The New York Times when compared with Vice. When two articles were written about unemployment due to Covid- 19, The New York Times was one-sided. The New York Times had only included one source of information, an interviewee, Nadine Josephs, unemployed. Whereas Vice had used multiple sources, information from the Labor Department and quotes from the National Multifamily Housing council.

The research is subjected to limitations as it relies on only four months' worth of newspaper articles related to Covid-19 therefore accurate conclusions of the news coverage for both mainstream and alternative could not be generalized. As the articles and themes chosen were based on our own assessments, a form of bias is presented. Therefore, future researchers should use a sample drawn randomly throughout a duration period to eliminate selection bias. Furthermore, New York Times's articles are only available for a period of time as it requires a paid subscription, whereas Vice is free. Future researchers should examine news outlets that do not require subscriptions as it is more cost and time efficient. Lastly, as the article only examines the search period of four months prior to the first Covid-19 case in New York, the analysis could not tell how the representations changed after or during the time period. Consequently, future researchers should take a more longitudinal approach to examine an accurate depiction of mainstream and alternative news websites.

\section{Acknowledgements}

Irdina Damia Muhammad Adam Mikhail Lim

Ian Isaiah Anak Danald

Nur Medina Azziera Azman Zaini

Hazel Hoh Yuen Hei

\section{Reference}

Alvernia (2019). The agenda-setting theory in mass communication. Alvernia Online. https://online.alvernia.edu/articles/agenda-setting-theory/

Bengtsson, M. (2016). How to plan and perform a qualitative study using content analysis. NursingPlus Open, 2: 814. Available: https://www.sciencedirect.com/science/article/pii/S2352900816000029

Cheung, Z. B. and Forsh, D. A. (2020). Early outcomes after hip fracture surgery in COVID- 19 patients in New York City. Journal of Orthopedics, 21: 291-96. Available: https://www-sciencedirectcom.ezproxy.taylors.edu.my/science/article/pii/S0972978X20302087

Dowd, M. (2020). Opinion - Lets 'Kick Coronavirus's Ass'. In this nightmarish moment, we're feeling warm and fuzzy about the cold and calculating Andrew Cuomo. Available: https://www.nytimes.com/2020/03/27/opinion/sunday/cuomo-new-york-coronavirus.html

First Versions (2015). The New York Times. Available: https://www.firstversions.com/2014/12/the-new-york$\underline{\text { times.html }}$

Fredi, M., Cavazzana, I., Moschetti, L., Andreoli, L., Franceschini, F., Airò, P., Bazzani, C., Crisafulli, F., Filippini, M., Frassi, M., Gerardi, M. C., Gorla, R., Lazzaroni, M. G., Lini, D., Nalli, C., Panaro, S., Piantoni, S., Regola, F., Taglietti, M., Tincani, A., Toniati, P., Vojinovic, T. and Zingarelli, S. (2020). COVID-19 in patients with rheumatic diseases in northern Italy: A single-centre observational and case-control study. The Lancet Rheumatology, 2(9): Available: https://www.thelancet.com/journals/lanrhe/article/PIIS2665-9913(20)30169-7/fulltext

Goldstein, J. and McKinley, J. (2020). Coronavirus in N.Y.: Manhattan woman is first confirmed case in state. The New York Times. https://www.nytimes.com/2020/03/01/nyregion/new-york-coronvirus-confirmed.html

Harding, J. (2020). Kick coronavirus ass': As NY outbreak worsens, Cuomo says mission is to save lives'. Available: $\quad$ https://auburnpub.com/news/local/govt-and-politics/kick-coronavirus-ass-as-ny-outbreakworsens-cuomo-says-mission-is-to-save-lives/article 84c042d0-1355-5101-8781-7a7e888d8ff8.html

Honigsbaum, M. (2020). The Pandemic Century. Penguin Random House: United Kingdom.

Lai, A. Y. H. (2018). Agility amid uncertainties: evidence from 2009 A/H1N1 pandemics in Singapore and Taiwan. Policy and Society, 37(4): 459-72. 
LaMarco, N. (2018). Mainstream vs. Alternative media. Chron.Com. Available: https://smallbusiness.chron.com/mainstream-vs-alternative-media-21113.html

Ma, S., Lai, X., Chen, Z., Tu, S. and Qin, K. (2020). Clinical characteristics of critically ill patients co-infected with SARS-CoV-2 and the influenza virus in Wuhan, China. International Journal of Infectious Diseases, 96: 683-87.

Myers Meghann (2020). The Army Corps of Engineers has two or three weeks to get thousands of new hospital beds up and running. Military Times. https://www.militarytimes.com/news/your-military/2020/03/27/the-armycorps-of-engineers-has-two-or-three-weeks-to-get-thousands-of-new-hospital-beds-up-and-running/

NYSDOH COVID-19 Tracker (2020). New York state department of health. Archived from the original on March 17, 2020. Available: https://covid19tracker.health.ny.gov/views/NYS-COVID19Tracker/NYSDOHCOVID-19Tracker-Map?\%3Aembed=yes\&\%3Atoolbar=no\&\%3Atabs=n

NYTCO (2018). Company | The New York Times Company. The New York Times Company. https://www.nytco.com/company/

Palaiodimos, L., Kokkinidis, D. G., Li, W., Karamanis, D., Ognibene, J., Arora, S., Southern, W. N. and Mantzoros, C. S. (2020). Severe obesity, increasing age and male sex are independently associated with worse inhospital outcomes, and higher in-hospital mortality, in a cohort of patients with COVID-19 in the Bronx, New York. Metabolism, 108: 154262. Available: https://www-sciencedirectcom.ezproxy.taylors.edu.my/science/article/pii/S0026049520301268

Sdun, M. (2015). From the Voice to VICE - a short history of VICE MEDIA. WPI.: Available: https://worldpressinstitute.org/from-the-voice-to-vice-a-short-history-of-vice-media/

Shen, M., Peng, Z., Guo, Y., Rong, L., Li, Y., Xiao, Y., Zhuang, G. and Zhang, L. (2020). Assessing the effects of metropolitan-wide quarantine on the spread of covid-19 in public space and households. International Journal of Infectious Diseases: 96 . Available: https://www.sciencedirect.com/science/article/pii/S120197122030326X

Theory, C. (2014). Agenda setting theory. Communication theory. Available: https://www.communicationtheory.org/agenda-setting-theory/

Travis, C. (n.d). VICE media becomes one of first news organizations to go Pure-IP. . Available: https://www.imaginecommunications.com/vice-media-becomes-one-first-news-organizations-go-pure-ip

Wiedeman, R. (2018). Vice media was built on a bluff. What happens when it gets called? Intelligencer. Available: https://nymag.com/intelligencer/2018/06/inside-vice-media-shane-smith.html 